\title{
ANALISIS KOMITMEN DAN KOMPETENSI DAN DAMPAK PADA KINERJA GURU PADA SMAN 1 BANGKINANG KOTA
}

\author{
Suarni Norawati ${ }^{1}$; Robbi Abdillah ${ }^{2}$; Nurman Zakaria $^{3}$ \\ Sekolah Tinggi Ilmu Ekonomi Bangkinang \\ Jln. Dr. A. Rahman Saleh No.54 A Bangkinang \\ E-mail : suarninorawati@pascabangkinang.ac.id \\ diterima: 12/3/2021; direvisi: 03/4/2021; diterbitkan: 26/9/2021
}

\begin{abstract}
Research to determine the effect of commitment and competence on the teacher performance with simulthan and partial at the SMAN 1 Bangkinang City. Types and sources of data used in this study are primary data and secondary data, while data collection techniques used in this study were questionnaires, file research, observation and interviews. The population in this study were all teachers at the SMAN 1 Bangkinang in 2019, amounting to 54 teachers and all teachers were sampled so that the sampling technique in this research used a saturated census technique. Data analysis was performed using multiple linear regression models. Based on the simulthan test results, the variable of commitment and competence have a significant effect with together on the teacher performance at the SMAN 1 Bangkinang City, while based on the partial test results, the variable of commitment and competence have a significant effect with individual on the teacher performance at the SMAN 1 Bangkinang City. The closeness of the relationship that occurs between the atractiveness of commitment and competence on the teacher at SMAN 1 Bangkinang City performance is very strong with a correlation coefficient $\mathrm{R}$ of $87,4 \%$. While contribution of independent variables to the dependent variables is equual to $75,4 \%$ while the remaining $24,6 \%$ is influenced by other variables not examined in this study.
\end{abstract}

Keywords: Commitment, Competence and Teacher Performance

\section{PENDAHULUAN}

Pendidikan memilikiperan yang sangat penting dalam pembangunan nasional karena pendidikan menjadi salah satu cara dalam membentuk Sumber Daya Manusia (SDM)yang berkualitas agar tercapainya tujuan pembangunan nasional. Sebagai generasi penerus bangsa, maka perkembangan kemajuan bangsa sedikit banyak berada ditangan generasi muda. Sehingga dalam hal ini maka pendidikan pada generasi muda diharapkan akan mampu mendukung pencapaian tujuan pembamgunan nasional yaitu menciptakan generasi muda yang berpendidikan dan berprestasi serta diharapkan akan mampu membawa negeri ini menghadapi persaingan global, khususnya dalam bidang pendidikan.

$$
\text { Berdasarkan Undang-Undang }
$$

Nomor 20 Tahun 2013 Tentang Sistem Pendidikan Nasional menyebutkan bahwa pendidikan nasional bertujuan untuk mengembangkan kemampuan dan membentuk watak serta peradaban bangsa, yang bermartabat dalam rangka mencerdaskan kehidupan bangsa, bertujuan untuk berkembangnya potensi peserta didik agar menjadi manusia yang beriman dan bertaqwa kepada Tuhan yang Maha Esa, berakhlak mulia, sehat, berilmu, cakap, kreatif, mandiri dan menjadi warga negara yang demokratis serta bertanggung jawab. Selanjutnya, berdasarkan Undang-Undang Nomor 23 Tahun 2014 tentang Pemerintah Daerah menyebutkan bahwa pemerintah daerah bertanggung jawab terhadap pendidikan setingkat SD/SMP, sedangkan pemerintah provinsi bertanggung jawab atas pendidkan setingkat SMA/SMK. Sementara pendidikan tinggi menjadi ranah dan tanggung jawab pemerintah pusat.

Kinerja akan realisasi perwujudan dari kemampuan dalam bentuk karya nyata yang merupakan hasil kerja yang dicapai pegawai dalam mengemban tugas pekerjaannya (Donni,2016:269). Dengann kinerja guru yang baik, diharapkan agar 
sekolah tersebut dapat mencapai tujuannya. Begitu juga dengan SMAN 1 Bangkinang Kota yang menjadi lokus dalam penelitian ini. Untuk mencapai visinya yaitu "terdepan dalam pretasidan teladan dalam prilaku berlandaskan iman dan taqwa terhadap Tuhan yang Maha Esa.

Penilaian kinerja guru dalam proses pembelajaran yang berkaitan dengan tugas utamanya sebagai seorang pendidik diatur dalam Juknis Peraturan Menteri Pendidikan Naional Nomor 35 Tahun 2010, yang menyatakan bahwa penilaian kinerja guru kelas/mata pelajaran dan guru BK/konselor dilakukan dengan mengacu kepada dimensi utama guru yang meliputi kegiatan merencanakan dan melaksanakan pembelajaran, mengevaluasi dan menilai termasuk didalamnya menganalisis hasil penilaian kemudian diturunkan menjadi indikator kinerja terukur sebagai bentuk unjuk kerja guru dalam melaksanakan tugasnya yang tertuju pada sasaran kinerja dengan kriteria Sangat Baik (SB), Baik (B), Cukup Baik (CB), Tidak Baik (TB) dan Sangat Tidak Baik (STB). Adapun pencapaian kinerja guru PNS pada SMAN 1 Bangkinang Kota dalam lima tahun terakhir dapat dilihat pada Tabel 1

Tabel 1. Kinerja Guru PNS SMAN 1 Bangkinang Kota, 2015-2019

\begin{tabular}{ccc}
\hline Tahun & Jumlah & Kinerja Guru \\
& Guru
\end{tabular}

\begin{tabular}{ccccccc}
\cline { 3 - 7 } & & SB & B & CB & TB & STB \\
2015 & 55 & 30 & 10 & 15 & - & - \\
2016 & 55 & 28 & 14 & 13 & - & - \\
2017 & 56 & 28 & 16 & 10 & 2 & - \\
2018 & 56 & 33 & 16 & 5 & 2 & - \\
2019 & 54 & 30 & 19 & 5 & - & - \\
\hline \multicolumn{5}{l}{ Sumber: SMAN 1 Bangkinang Kota, Tahun 2020 }
\end{tabular}

Dari Tabel 1 diatas dapat dilihat bahwa dalam lima tahun terakhir, kinerja guru PNS pada SMAN 1 Bangkinang Kota masih belum optimal, karena berdasarkan data hasil prasurvey diketahui masih ada guru yang memiliki nilai kinerja yang tidak baik. Hal ini dapat kita lihat bahwa masih terdapat guru dengan kategori kinerja Cukup Baik atau Tidak
Baik. Berdasarkan hasil wawancara dengan salah seorang staf pada SMAN 1 Bangkinang Kota, masih belum optimalnya kinerja guru PNS pada SMAN 1 Bangkinang Kota diindikasikan karena kurang mampunya guru dalam membuat perencanaan pengajaran yang baik, kurang terampil dalam menggunakan media pembelajaran, sistem belajar yang tidak berdasarkan model pengajaran yang telah ditetapkan, kurang mengaktifkan siswa dalam belajar, metode pembelajaran yang masih konvensional serta monotolik dan lain sebagainya.

Berdasarkan hal tersebut, tentunya hal ini perlu mendapat perhatian kepala sekolah SMAN 1 Bangkinang Kota yaitu dengan memperhatikan faktor-faktor yang mempengaruhi kinerja guru itu sendiri yang diantaranya adalah komitmen dan kompetensi.

Komitmen guru terhadap lembaga sekolah sebagai organisasi pada dasarnya merupakan suatu kondisi yang dirasakan oleh guru dan dapat menimbulkan prilaku positif yang kuat terhadap organisasi kerja yang dimiliki dan berkaitan dengan identifikasi dan loyalitas pada organisasi dan tujuan-tujuannya (Kusmayarni, 2011:42).

Berdasarkan hasil penelitian, diperoleh informasi bahwa peningkatan prestasi siswa belum optimal karena nilai rata-rata UN siswa SMAN 1 Bangkinang Kota dalam lima tahun terakhir terjadi penurunan secara umum. Hal ini menunjukkan bahwa komitmen guru dalam meningkatkan mutu dan kualitas pendidikan pada siswa SMAN 1 Bangkinang Kota masih belum memberikan hasil yang diharapkan. Oleh karena itu, perlu adanya upaya dalam meningkatkan komitmen guru pada SMAN 1 Bangkinang Kota sehingga dengan mempunyai komitmen yang tinggi dalam upaya mencerdaskan anak bangsa diharapkan agar siswa tersebut akan berprestasi, berkualitas dan memiliki pola pikir maju. 
Jurnal Ilmiah Ekonomi dan Bisnís

Vol. 18. No.2,September 2021: 166-175

EISSN : $2442-9813$

ISSN : $1829-9822$

Kompetensi menunjukkan sebuah keahlian dan keterampilan dasar serta pengalaman yang dimiliki oleh seorang guru yang dapat mempengaruhi mereka dalam melaksanakan proses beajar dan mengajar atau tugas lainnya secara efektif dan efisien atau sesuai dengan standar sebuah organisasi pendidikan yang telah ditentukan (Kusmayarni, 2011:84).

Indikator dari kompetensi diantaranya pendidikan. Seorang guru hendaknya mengajar siswanya berdasarkan pendidikan yang dimilikinya. Berdasarkan hasil penelitian diketahui bahwa saat ini masih terdapat guru SMAN 1 Bangkinang yang mengajar tidak linear dengan pendidikan yang dimilikinya. Peran guru sebagai salah satu komponen yang menempati posisi sentral dan sangat strategis dalam sistem pendidikan karena guru menentukan terselenggaranya pendidikan yang bermutu.

Berdasarkan uraian diatas, maka rumusan masalah dalam penelitian ini adalah apakah komitmen dan kompetensi berpengaruh secara simultan dan parsial terhadap kinerja guru pada SMAN 1 Bangkinang Kota.Sedangkan tujuan penelitian ini adalah untuk mengetahui pengaruh komitmen dan kompetensisecara simultan dan parsial terhadap kinerja guru pada SMAN 1 Bangkinang Kota.

\section{TINJAUAN PUSTAKA}

Kinerja guru dapat dilihat dari hasil realisasi kerja yang dimiliki oleh seorang guru seperti kemampuan seorang guru dalam mendidiksertamelaksanakan tugas-tugas dan kewajibannyasecara layak dan bertanggung jawab. Kinerja guru dapat pula diartikan sebagai suatu perilaku atau respon guru yang mengacu pada hasil yang mereka kerjakan untuk memberikan hasil dan tujuan suatu dunia pendidikan yang meliputi merencanakan program belajar mengajar, melaksanakan dan mengelola proses belajar mengajar, menilai kemajuan proses belajar mengajar dan menguasai bahan

pelajaran(Azwar,2013:46).

Kinerja guru merupakan pencapaian hasil kerja seorang guruyang disesuaikan dengan peran dan tugasnya didalam dunia pendidikan dalam suatu periode tertentu yang dihubungkan dengan ukuran nilai atau standart tertentu dari organisasi pendidikan tempat guru tersebut bekerja. Sehingga dalam hal ini maka kinerja gurujuga diartikan sebagai hal yang bersifat individual karena setiap guru mempunyai tingkat kemampuan yang berbeda-beda dalam mengerjakan tugasnya yaitu sebagai pendidik.

Guru dalam melaksanakan tugas dan tanggung jawabnya dapat dinilai dari kegiatan belajar mengajar yang dilaksanakan melalui prosedur yang tepat yaitu dengan membuat persiapan mengajar berupa menyusun persiapan tertulis, mempelajari pengetahuan yang akan diberikan atau keterampilan yang akan dipraktekkan dikelas, menyiapkan media dan alat-alat pengajaran yang lain serta menyusun alat evaluasi, melaksanakan pengajaran dikelas berupa membuka dan menutup, memberikan penjelasan, memberikan peragaan, mengoperasikan alat-alat pelajaran serta alat bantu yang lain, mengajukan pertanyaan serta memberikan jawaban melakukan program remedial serta melakukan pengukuran hasil belajar berupa pelaksanaan kuis (pertanyaan singkat), melaksanakan tes tertulis, mengoreksi, memberikan skor dan menentukan hasil akhir (Suharsini,2013:22).

Komitmen seorang guru sangat penting karena guru yang memiliki tujuan yang kuat akan menampilkan kinerja terbaiknya serta produktif dalam mengemban pekerjaannya, sehingga dalam hal ini maka keberhasilan manajemen suatu organisasi pendidikan salah satunya ditentukan oleh keberhasilan manajemen dalam menumbuhkan komitmen daya pengajarnya.Untuk mempertahankan dan menjadi bagian penting dari anggota organisasi pendidik demi tercapainya tujuan 
organisasi pendidikan maka komitmen seorang guru ditunjukkan dalam sikap penerimaan, keyakinan yang kuat terhadap nilai-nilai dan tujuan organisasi begitu juga adanya dorongan yang kuat.

Adapun jenis-jenis komitmen seperti komitmen afektif (continuance commitment) yang merupakan keinginan sorang guru untuk tetap menjadi bagian dari organisasi pendidikan dengan pertimbangan bahwa jika ia keluar maka ia akan menghadapi resiko kerugian, komitmen normatif (normative commitment) yang merupakan komitmen yang didasarkan pada norma yang ada dalam diri pegawai yang berisi keyakinan pegawai akan tanggung jawab didalam pekerjaannya dan komitmen kontinu (continuance commitment) merupakan komitmen yang didasarkan akan kebutuhan rasional yang dengan kata lain komitmen ini terbentuk atas dasar untung rugi, dipertimbangkan atas apa yang harus dikorbankan bila akan menetap pada pekerjaannya (Mulyasa, 2013:55).

Komitmen seorang guru sebagai daya pengajar dapat ditingkatkan melaui adanya keadilan dan kepuasan kerja yang dirasakan guru karenakomitmen guru akan sulit untuk dicapai jika guru tersebut menghadapi beban kerja yang meningkat namun justru keuntungan yang diperoleh hanya dinikmati oleh pimpinan atau manajer tingkat atas saja,kenyamanan kerja dimana guru membutuhkan hubungan kerja yang saling timbal balik dengan organisasi pendidikan sehingga dalam hal ini makakemanan kerja guru harus selalu diperhatikan untuk memlihara hubungan dimana pegawai percaya usaha mereka akan dihargai oleh pihak pimpinan dalam organisasi pendidikan, pemahaman organisasi dimana hal ini menunjukkan identifikasi guru secara personal terhadap organisasi pendidikan.

Hal ini akan menunjukkan suatusikap yang akan menguat ketika gurutersebut memiliki pemahaman terhadap organisasi pendidikan, adanya keterlibatan guru yang merupakan bagian dari organisasi pendidikan dimanadalam hal ini maka guru diharapkan ikut berpartisipasi dalam pengambilan keputusan yang menyangkut masa depan organisasi pendidikan serta berupaya dalam meningkatkan kepercayaan guru terhadap orgaisasi pendidikan tempat guru tersebut mengajar (McShane dan Glinow dalam Donni, 2016:245).

Kompetensi dalam sebuah organisasi sangat diperlukan terutama dalammelaksanakan tuntutan organisasi, diman dengan adanya perubahan yang sangat cepat karena adanya perkembangan masalah yang sangat kompleks dan dinamis serta ketidakpastian masa depan dalam tatanan kehidupan. Biasanya sebuah organisasi menggunakan kompetensi yang kemudian diidentifikasi untuk membantu menyaring untuk menemukan kandidat terbaik, mengevaluasi, menentukan kompensasi dan membantu membuat keputusan yang lebih baik mengenai pelatihan, kenaikan jabatan dan penugasan seorang pegawai (Hasibuan, 2012:56).

Mulyasa (2013:126), mengartikan kompetensi sebagai karakteristik mendasar yang dimiliki seseorang yangkemudian akan berpengaruh langsung terhadap hasil kerjanya sehingga akan dapat dinilai apakah pekerjaan tersebut sudah terlaksana dengan baik atau belum baik. Kompetensi seseorang sangat besar dapat dipengaruhi oleh beberapa faktor, baik dari dalam (internal) maupun dari luar (eksternal) diataranya disebabkan oleh bakat bawaan yang merupakan bakat yang sudah ada dan melekat sejak mereka dilahirkan, motivasi kerja yang tinggi dan keterampilan atau keahlian yang dimiliki,sikap, motif, dan nilai cara pandang, pengetahuan yang dimiliki baik dari pendidikan formal maupun non formal (pelatihan, course, panel dan lain-lain) serta lingkungan hidup dari kehidupan mereka sehari-hari.

Menurut Simamora (2014:228), ada empat komponen utama pembentukan kompetensi yaitu pengetahuan yang 
Jurnal Ilmiah Ekonomi dan Bisnís

Vol. 18. No.2,September 2021: 166-175

EISSN : $2442-9813$

ISSN : $1829-9822$

merupakkan informasi yang dimiliki oleh seseorang, keterampilan yang menjadi faktor dalam mensukseskan pencapaian tujuan organisasi.

Di duga komitmen dan kompetensi berpengaruh secara simultan dan parsial terhadap kinerja guru pada SMAN 1 Bangkinang Kota.

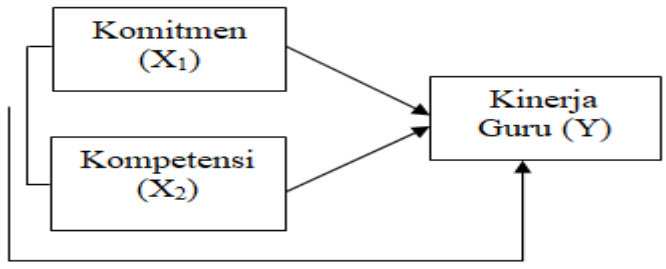

Variabel penelitian ini adalah :

1. Kinerja merupakan tingkat keberhasilan pegawai dalam menyelesaikan pekerjaannya. Kinrja bukan merupakan karakteristik individu, seperti bakat atau kemampuan, namun merupakan perwujudan dari bakat atau kemampuan itu sendiri. (Sumber: Donni, 2016:269). Indikator dari variable ini adalah kuantitas pekerjaan (quantity of work), kualitas pekerjaan (quality of work), kemandirian (dependebility,) inisiatif (initiative), adaptabilitas (adabtability) dan kerjasama (cooperation) (Sumber: Mondy, Noe dan Premeaux dalam Donni, 2016:271).

2. Komitmen merupakan loyalitas pegawai terhadap organisasi, yang tercermin dari keterlibatannya yang tinggi untuk mencapai tujuan organisasi. Loyalitas pegawai tercermin melalui kesediaan dan kemauan pegawai untuk selalu berusaha menjadi bagian dari organisasi serta keinginannya yang kuat untuk bertahan dalam organisasi (Sumber: Donni, 2016:234). Indikator dari variabel ini adalah keadilan dan kepuasan kerja, kemanan kerja, pemahaman organisasi, keterlibatan pegawai dan kepercayaan pegawai (Sumber: McShane dan Glinow dalam Donni, 2016:245).
Kompetensi adalah peta kapasitas pegawai atas atribut pekerjaan yang diembannya dan merupakan kumpulan dari kemampuan, keterampilan, kematanngan, pengalaman, keefektifan, keefesienan dan kesuksesan dalam mengemban taggug jawab pekerjaan (Sumber: Donni, 2016: 254). Indikator dari variabel ini adalah motif, watak, konsep diri, pengetahuan dan keterampilan (Spancer dalam Donni, 2016:258).

\section{METODE PENELITIAN}

Penelitian ini dilaksanakan pada SMAN 1 Bangkinang Kota.Penelitian ini dilaksanakan selama 2 bulan yaitu pada bulan Juni sampai dengan bulan Agustus Tahun 2020.Jenis data yang digunakan dalam penelitian ini adalah data primer dan sekunder.Sedangkan teknik pengumpulan data yang digunakan dalam penelitian ini adalah dengan melalui penyebaran koesioner, file research, observasi dan wawancara.

Populasi dalam penelitian ini adalah seluruh guru pada SMAN 1 Bangkinang Kota Tahun 2019 yang berjumlah 54 orangdan seluruh gurutersebut dijadikan sampel sehingga teknik pengambilan sampel dalam penelitian ini menggunakan teknik sensus jenuh. Analisa data pada penelitian ini dilakukan dengan model persamaan regresi linear berganda dengan persamaan sebagai berikut :

$Y=\alpha+\beta_{1} X_{1}+\beta_{2} X_{2}+\varepsilon$

Keterangan: $Y=$ Kinerja guru, $\alpha=$ Konstanta, $\beta_{1}, \beta_{2}=$ Koefisien regresi, $X_{1}=$ Komitmen, $\mathrm{X}_{2}=$ Kompetensi dan $\varepsilon=$ Error term.Selanjutnya pengujian hipotesis dalam penelitian ini menggunakan uji $\mathrm{F}$ dan uji $\mathrm{t}$ dengan alpha $5 \%$

\section{HASIL DAN PEMBAHASAN}

Berdasarkan hasil pengolahan data dengan program SPSS (Statistical Product and ServiceSolution) versi 25.00 diperoleh hasil sebagai berikut :

$Y=20,013+0,332 X_{1}+0,355 X_{2}$ 
Dari persamaan diatas diketahui nilai konstan $(\alpha)$ sebesar 20,013. Angka ini bertanda positif dan memberikan arti bahwa jika diasumsikan komitmen tidak ada $\left(\mathrm{X}_{1}=0\right)$ dan kompetensi tidak ada $\left(\mathrm{X}_{2}=0\right)$, maka kinerja guru (Y) pada SMAN 1 Bangkinang Kota masih ada sebesa 20,013 satuan. Koefisien regresi variabel komitmen $\left(\mathrm{X}_{1}\right)$ adalah sebesar 0,332 . Angka ini bertanda positif dan memberikan arti jika diasumsikan komitmen $\left(\mathrm{X}_{1}\right)$ meningkat sebesar $1 \%$, sementara kompetensi konstan atau tidak mengalami perubahan maka kinerja guru pada SMAN 1 Bangkinang Kota akan meningkat sebesar $332 \%$ dan begitu juga sebaliknya. Koefisien regresi variabel kompetensi $\left(\mathrm{X}_{2}\right)$ adalah sebesar 0,355. Angka ini bertanda positif dan memberikan arti jika diasumsikan kompetensi $\left(\mathrm{X}_{2}\right)$ meningkat sebesar $1 \%$, sementara komitmen konstan atau tidak mengalami perubahan maka kinerja guru pada SMAN 1 Bangkinang Kota akan meningkat sebesar $335 \%$ dan begitu juga sebaliknya. Selanjutnya hasil pengujian hipotesis secara simultan dalam penelitian ini seperti yang terlihat pada Tabel 2

Tabel 2. Hasil Uji Hipotesis Secara Simultan (UjiF)

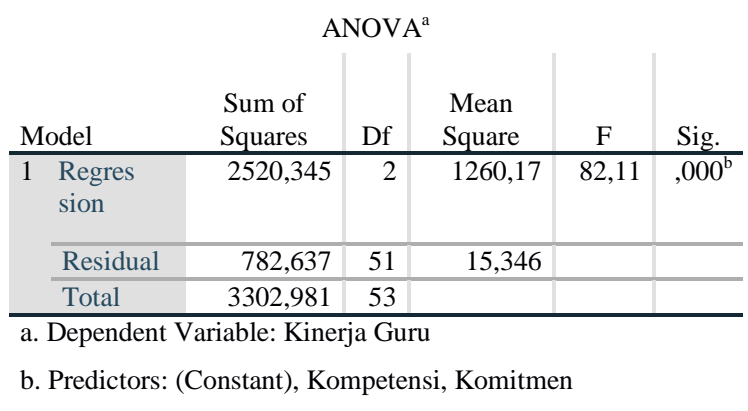

Sumber:Data Olahan, 2020

Dari Tabel 2 dapat dilihat nilai Fhitung sebesar 82,118 dengan nilai signifikansi sebesar 0,000. Hasil ini memberikan arti bahwa memang benar terdapat pengaruh yang signifikan antara variabel komitmen dan kompetensi terhadap kinerja guru pada SMAN 1 Bangkinang Kota, karena nilai F-hitung lebih besar dari F-tabel yaitu 115,217 > 4,020 atau sinifikansi lebih rendah dari nilai alpha yaitu $0,000<0,050$. Dengan demikian hipotesis secara simultan dalam penelitian ini dapat diterima pada tingkat keyakinan $95 \%$.

Hasil pengujian hipotesis secara parsial dalam penelitian ini seperti yang terlihat pada Tabel 3 .

Tabel 3. Hasil Uji Hipotesis Secara Parsial

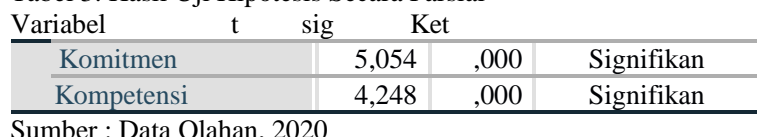

Dari Tabel 3 diketahui nilai t-hitung variabel komitmen $\left(\mathrm{X}_{1}\right)$ sebesar 5,054 dengan nilai signifikansi sebesar 0,000 . Sementara t-tabel pada $\mathrm{n}=54$ dan alpha $5 \%$ diperoleh sebesar 1,675. Hasil ini memberikan arti bahwa memang benar terdapat pengaruh yang signifikan secara parsial dari variabel komitmen terhadap kinerja guru pada SMAN 1 Bangkinang Kota, hal ini dapat diterima pada tingkat keyakinan 95\% karena nilai signifikansi variabel komitmen lebih rendah dari nilai alpha yaitu $0,000<0,050$ atau t-hitung lebih besar dari t-tabel yaitu 5,054 > 1,675.

Nilai t-hitung variabel kompetensi $\left(\mathrm{X}_{2}\right)$ sebesar 4,248 dengan nilai signifikansi sebesar 0,000. Sementara t-tabel pada $\mathrm{n}=54$ dan alpha 5\% diperoleh sebesar 1,675. Hasil ini memberikan arti bahwa memang benar terdapat pengaruh yang signifikan secara parsial dari variabel kompetensi terhadap kinerja guru pada SMAN 1 Bangkinang Kota, hal ini dapat diterima pada tingkat keyakinan $95 \%$ karena nilai signifikansi variabel kompetensilebih rendah dari nilai alpha yaitu $0,000<0,050$ atau t-hitung lebih besar dari t-tabel yaitu $4,248>1,675$. Selanjutnya, dari hasil pengolahan data tersebut, variabel yang dominan mempengaruhi kinerja guru pada SMAN 1 Bangkinang Kota adalah variabel kompetensi karena variabel tersebut memiliki koefisien regresi lebih besar dari pada variabel komittmen.

Hasil pengujian koefisien korelasi dan determinasi dalam penelitian ini seperti yang terlihat pada Tabel 4 
Jurnal Ilmiah Ekonomí dan Bísnis

Vol. 18. No.2,September 2021 : 166-175

EISSN : $2442-9813$

ISSN : $1829-9822$

Tabel 4. Koefisien Korelasi (R) dan Determinasi $\left(\mathrm{R}^{2}\right)$

\begin{tabular}{lrrr}
\hline $\mathrm{R}$ & R Square & $\begin{array}{c}\text { Adjusted R } \\
\text { Square }\end{array}$ & $\begin{array}{c}\text { Std. Error } \\
\text { of the } \\
\text { Estimate }\end{array}$ \\
\hline $874^{\mathrm{a}}$ &, 763 &, 754 & 3,917 \\
\hline
\end{tabular}

Sumber:Data Olahan, 2020

Dari Tabel 4, diketahui bahwa nilai

koefisien (R) diperoleh sebesar 0,874 , hal ini memberi arti bahwa variabel komitmen dan kompetensi keeratan hubungannya berada dalam kategori sangat kuat terhadap kinerja guru pada SMAN 1 Bangkinang Kota. Selanjutnya koefisiensi determinasi $\left(\mathrm{R}^{2}\right)$ dapat dilihat dari besarnya adjusted $R$ square yang diperoleh yaitu sebesar 0,754, hal ini memberi arti bahwa besarnya kontribusi variabel komitmen dan kompetensi terhadap kinerja guru pada SMAN 1 Bangkinang Kota adalah sebesar 75,4\% dengan interprestasi berada pada kategori kuat, sedangkan sisanya sebesar $24,6 \%$ ditentukan oleh variabel lain yang tidak diteliti dalam penelitian ini.

Dari hasil penelitian sebelumnya, diketahui bahwa berdasarkan hasil pengujian hipotesis secara simultan (uji-F) dalam penelitian ini menunjukkan bahwa variabelkomitmen dan kompetensiterbukti signifikan berpengaruhsecara bersamasama terhadap kinerja guru pada SMAN 1 Bangkinang Kota, dengan keeratan hubungan yang terjadi antara variabel komitmen dan kompetensi terhadap kinerja guru adalah sangat kuat terhadap kinerja guru pada SMAN 1 Bangkinang Kota. Hal ini sesuai dengan pendapat Yayat (2017:155), yang menyatakan bahwa kinerja guru hendaknya dikelola dan dan didayaguna serta dikembangkan secara maksimal untuk mencapai tujuan organisasi dan pengembangan individu guru itu sendiri. Kinerja guru dapat ditingkatkan melalui peningkatan komitmen karena dengan dengan adanya komitmen yang kuat didalam diri guru tersebut akan mampu meningkatkan semangat, kemauan dan ketelitian guru pada saat mengajar didalam kelas, fokus, dan disiplin. Selain hal tersebut, kinerja guru juga akan meningkat seiring dengan meningkatknya kompetensi yang dimiliki oleh guru itu sendiri karena guru yang berkompetensi akan mampu melaksanakan pekerjaannya secara maksimal.

Hal ini didukung oleh teori Uzer (2012:232), yang menjelaskan bahwa dalam mencapai tujaun pendidikan yang baik, maka kinerja gurumenjadi aspek penting yang harus diperhatikan oleh pihak pimpinan. Guru akan bekerja dengan produktif berkaitan dengan banyak faktor diantaranya adalah insentif, komitmen, motivasi, kompetensi, kepuasan kerja, tingkat stres, kondisi fisik pekerjaan, sistem kompensasi, desain pekerjaan dan aspekaspek ekonomis, teknis serta berbagai faktor lainnya. Untuk mencapai kinerja yang baik maka dibutuhkan kerjasama tim atau hasil individu yang baik pula. Hal ini juga didukung oleh teori Umar (2016:11), gaya manajemen dalam mengelola sumber daya yang ada akan berorientasi pada kinerja dengan melakukan proses komunikasi secara terbuka dan berkelanjutan sehingga mampu menciptakan visi bersama dan pendekatan strategis serta terpadu sebagai kekuatan pendorong untuk mencapai tujuan organisasi. Kenaikan maupun kinerja akan ditentukan oleh seberapa besar intensitas komitmen yang dimilikinya dalam bekerja serta seberapa besar kemampuan yang dimilikinya dalam melaksanakan pekerjaan secara maksimal sesuai dengan tuntuntan tugas yang harus dilaksanakan.

Hasil dari penelitian ini sama dengan hasil penelitian yang dilakukan oleh Prapti Ningsih (2019) yang menyimpulkan bahwa variabel komitmen, kompetensi dan lingkungan kerja berpengaruh secara simultan dan parsial terhadap kinerja guru di Kecamatan Pasangkayu Kabupaten Mamuja Utara. Hal yang sama juga diteliti oleh Yohanes Sukamto dan Pardjono (2016) yang menyimpulkan bahwa kompetensi guru, komitmen kerja dan motivasi kerja berpengaruh secara simultan 
dan parsial terhadap kinerja guru SMP Andalan di Sleman.

Hasil uji hipotesis secara parsial (uji-t) dalam penelitian ini menunjukkan bahwa variabel komitmen terbukti berpengaruh signifikan secara parsial terhadap kinerja guru pada SMAN 1 Bangkinang Kota. Hasil ini didukung oleh pendapat yang dikemukakan oleh Kunandar (2016:79), yang menyatakan bahwa sebagai upaya peningkatan kinerja guru maka komiten guru merupakan kunci keberhasilan suatu sekolah dalam meningkatkan pencapaian belajar siswa yang ditunjukkan melalui komitmen aktif seorang guru terhadap pembelajaran siswa di kelas. Komitmen guru menggambarkan sebagai ketertarikan seorang guru secara psikologis dengan profesi mengajar, asosiasi profesional, sekolah, rekan kerja (kolega), orang tua, dan siswa. Selain itu, komitmen guru juga dianggap sebagai kunci dari budaya sekolah dan dapat ditunjukkan oleh proses pengajaran guru, dedikasi guru dalam meningkatkan prestasi siswa dan kesetiaan guru terhadap sekolahan.

Hasil ini juga didukung oleh teori yang dikemukakan Raharjo (2013:114), yang menyatakan bahwa peningkatan status pengajaran dan membangun komunitas di sekolah yang menghasilkan peningkatan komitmen guru yang pada akhirnya mengarah pada peningkatan kinerja guru dan pembelajaran siswa. Komitmen guru menjadi ikatan psikologis guru dengan profesinya dalam mengajar. Komitmen ini biasanya disesuaikan dengan melihat tingkat atriasi dan alasan guru untuk melakukan pertanyaan kepada mereka mengenai apakah mereka akan tetap memilih berkarir sebagai guru. Komitmen guru juga merupakan pusat untuk meningkatkan kinerja guru dan belajar siswa agar mengurangi pergantian guru.

Dalam peningkatan kinerja guru, proses belajar mengajar terus berlanjut sepanjang karir guru. Oleh karena itu, guru perlu mempersiapkan diri dan melakukan pembaharuan dalam mengajar. Komitmen guru dalam mengajar harus lebih baik dari waktu ke waktu. Komitmen menjadi tanggung jawab dalam pengembangan profesional guru. Asumsi tanggung jawab ini bentuk dari ide guru mengenai pembelajaran yang reflektif. Tingkat komitmen guru dianggap sebagai kunci keberhasilan dari agenda reformasi pendidikan. Untuk itu, guru perlu mempertahankan energi dan semangat mereka dalam mengajar. Komitmen dianggap sebagai sumber daya individu yang dikaitkan dengan karakteristik profesional seorang guru (Ling, 2012 : 98).

Hasil dari penelitian ini sama dengan hasil penelitian yang dilakukan oleh Siti Markonah (2017) yang menyimpulkan bahwa variabel komitmen terbukti berpengaruh positif secara parsial terhadap kinerja guru (studi kasus di SMA Negeri 1 Jakenan Kabupaten Pati). Hal yang sama juga diteliti oleh Haryaka (2015) yang menyimpulkan bahwa variabel komitmen terbukti berpengaruh positif secara parsial terhadap kinerja guru pada SMAN 1 Batanghari.

Hasil uji hipotesis secara parsial (ujit) dalam penelitian ini menunjukkan bahwa variabel kompetensi terbukti berpengaruh signifikan secara parsial terhadap kinerja guru pada SMAN 1 Bangkinang Kota. Hasil ini didukung oleh teori yang dikemukakan oleh Mohaimin (2013:76), yang menyatakan bahwa sebagai upaya dalam meningkatkan kinerja guru, kompetensi diartikan sebagai kemampuan untuk melakukan tindakan/perilaku rasional dalam melaksanakan tugas atau profesinya. Perilaku/tindakan dikatakan sebagai tindakan rasional karena memiliki tujuan dan arah yang jelas yakni untuk menjadikanpembelajaran lebih menarik dan menyenangkan sehingga para peserta mampu menangkap materi dengan lebih mudah. Kompetensi merupakan suatu komponen yang sangat penting dalam profesi seperti profesi pendidik baik bagi 


\section{Jurnal Ilmiah Ekonomi dan Bisnis}

Vol. 18. No.2,September 2021 : 166-175

EISSN : $2442-9813$

ISSN : $1829-9822$

guru ataupun dosen. Selanjutnya menurut Umar (2016:38), menyatakan bahwa sebagai upaya dalam meningkatkan kinerja guru, kompetensi diartikan sebagai gabungan dari semua kemampuan personal, sosial, teknologi, keilmuan dan spiritual atau keagamaan yang kesemuanya akan membentuk suatu standar kompetensi pendidik. Kompetensi merupakan komponen utama dari standar profesi di samping kode etik sebagai regulasi perilaku profesi yang ditetapkan dalam prosedur dan system pengawasan tertentu.

Pada dasarnya setiap orang yang menyampaikan ilmu kepada orang lain dapat disebut sebagai pengajar, namun tidak semua pengajar dapat disebut dengan guru yang professional. Guru yang profesional adalah guru yang bekerja sesuai dengan batasan profesi, yakni dilandasi pendidikan keahlian tertentu. tidak sama dengan seorang pekerja atau buruh yang tidak memerlukan keahlian tertentu. Keprofesionalan guru (guru yang memiliki kompetensi) saat ini dapat di ukur dengan beberapa kompetensi dan berbagai indikator yang melengkapinya, tanpa adanya kompetensi dan indikator itu maka sulit untuk menentukan keprofesionalan guru. Peningkatan kinerja dalam kompetensi guru dapat dilaksanakan melalui berbagai strategi dalam bentuk pendidikan dan pelatihan (Uzer, 2012: 46).

Hasil dari penelitian ini sama dengan hasil penelitian yang dilakukan oleh Prapti Ningsih (2019) yang menyimpulkan bahwa variabel kompetensi berpengaruh secara parsial terhadap kinerja guru di Kecamatan Pasangkayu Kabupaten Mamuja Utara. Hal yang sama juga diteliti oleh Yohanes Sukamto dan Pardjono (2016) yang menyimpulkan bahwa kompetensi guru berpengaruh secara parsial terhadap kinerja guru SMP Andalan di Sleman. Penelitian ini merupakan replikasi dari penelitian sebelumnya yaitu penelitian
Prapti Ningsih (2019). Perbedaan penelitian terletak pada lokus dan objek penelitian, sedangkan alat analisis data dan pengujian dilakukan dengan metode yang sama.

\section{KESIMPULAN DAN SARAN}

Berdasarkan hasil dan pembahasan, maka dapat ditarik kesimpulan dalam penelitian ini sebagai berikut: (1) Secara simultan, variabel komitmen dan kompetensi terbukti berpengaruh signifikan terhadap kinerja guru pada SMAN 1 Bangkinang Kota. (2) Secara parsial, variabel komitmen dan kompetensi terbukti berpengaruh signifikan terhadap kinerja guru pada SMAN 1 Bangkinang Kota dengan variabel kompetensi sebagai variabel yang dominan dalam mempengaruhi kinerja guru. (3) Kontribusi variabel komitmen dan kompetensi terhadap kinerja guru pada SMAN 1 Bangkinang Kota adalah sebesar 75,4\% sedangkan sisanya $24,6 \%$ dipengaruhi oleh variabel lain yang tidak diteliti dalam penelitian ini

Berdasarkan beberapa kesimpulan diatas, maka dapat diberikan saran sebagai berikut : (1) Pimpinan pada SMAN 1 Bangkinang Kota diharapkan mampu mendorong penciptaan komitmen bagi setiap guru PNS, seperti dengan adanya kebijakan kepala sekolah terhadap capaian pembelajaran, adanya pemberian motivasi dan lain sebaginya. (2) Pimpinan pada SMA N 1 Bangkinang Kota diharapkan dapat merumuskan kebijakan untuk peningkatan kompetensi guru, misalnya menfasilitasi guru-guru untuk mengkuti berbagai pelatihan-pelatihan, dalam rangka meningkatkan kompetensi guru.

\section{DAFTAR PUSTAKA}

Azwar, Teguh Sulistiani, 2013, Manajemen Kinerja Guru Profesional, Penerbit Gaya Media, Yogyakarta.

Cardoso, Faustino Gomes, 2013, Manajemen Sumber Daya Manusia, Edisi Terjemahan, Penerbit PT. Andi, Yogyakarta. 
Donni J, Priansa, 2016, Perencanaan dan Pengembangan SDM, Cetakan Kedua, Penerbit Alfabeta, Bandung.

Haryaka, 2015, Pengaruh Kompetensi dan

Komitmen Terhadap Kinerja Guru Pada SMAN 1 Batanghari. Jurnal Ilmu Pendidikan, Volume 9, Nomor 2, ISSN: 8812-8999.

Hasibuan, Malayu, 2012, Organisasi Dan Motivasi, Cetakan Keempat, Penerbit PT. Bumi Aksara, Jakarta.

Juknis Peraturan Menteri Pendidikan Nasional Nomor 35 Tahun 2010 Tentang Penilaian Kinerja Guru Kelas atau Mata Pelajaran

Kunandar, Faiz, 2016, Guru Profesional Implementasi KTSP dan Persiapan Menghadapi Sertifikasi Guru, Penerbit Rajagrafindo, Jakarta.

Kusmayarni, 2011， Komitmen Guru Dalam Pendidikan, Penerbit PT. Garda Persindo. Yogyakarta

Ling, Mey, 2012, Komitmen Guru Dalam Perspektif Kinerja Profesionalisme, Penerbit Refika, Bandung.

Moch.Aminudin, 2013, Pengaruh Komitmen Kerja, Kapabilitas Kerja dan Motivasi Terhadap Kinerja Pegawai Sekolah Tinggi Ilmu Ekonomi Nahdlatul Ulama' (STIENU) Jepara, Judul Ilmiah UNTAG Semarang, Volume 4, Nomor 3.

Mohaimin, Mujib, 2013, Pemikiran Pendidikan Indonesia Filosopin dan Kerangka Dasar Operasionalnya, Penerbit Trigenda Karya, Bandung.

Mulyasa, Erwin, 2013, Standart Kompetensi dan Sertifikasi Guru, Penerbit PT. Remaja Rosdakarya, Bandung.

Prapti Ningsih, 2019, Pengaruh Komitmen, Kompetensi dan Lingkungan Kerja Terhadap
Kinerja Guru di Kecamatan Pasangkayu Kabupaten Mamuja Utara, e-Jurnal Katalogis, Volume 5, Nomor 7, ISSN: 2302-2019.

Raharjo, Andesta, 2013, Perspektif Guru

Profesional, Penerbit Gramedia

Pustaka Utama, Jakarta.

Simamora, Henry, 2014, Manajemen Sumber Daya Manusia, Penerbit STIE YKPN, Bandung.

Siti Markonah, 2017, Pengaruh Motivasi, Kompetensi dan Komitmen Terhadap Kinerja Guru (Studi Kasus di SMA Negeri 1 Jakenan Kabupaten Pati), Jurnal Pendidikan Ilmu Pendidikan, Volume 6 Nomor 2, ISSN:98XX-99XX.

Suharsini, Arikunto, 2013, Evaluasi Program Pendidikan: Pedoman Teoritis Praktik Bagi Mahasiswa dan Praktis Bagi mahasiswa dan Praktis Pendidikan, Edisi Kedua, Penerbit Bumi Aksara, Jakarta.

Umar, Hamlik, 2016, Pendidikan Guru Berdasarkan Pendekatan Kompetensi, Bumi Aksara, Bandung

Undang-Undang Republik Indonesia Nomor 20 Tahun 2013 Tentang Sistem Pendidikan Nasional

Undang-Undang Republik Indonesia Nomor 23 Tahun 2014 Tentang Pemerintah Daerah

Uzer, Usman, 2012, Menjadi Guru Profesional, Penerbit Remaja Rosdakarya, Bandung.

Yayat, Herujito, 2017, Dasar-Dasar Manajemen, Penerbit Grasindo, Jakarta.

Yohanes Sukamto dan Pardjono, 2016, Pengaruh Kompetensi Guru, Komitmen Kerja dan Motivasi Kerja Terhadap Kinerja Guru SMP Andalan di Sleman, Jurnal Penelitian Ilmu Pendidikan, Volume 9, Nomor 2, ISSN: 99899988 